\title{
Subsidence and uplift of Sidoarjo (East Java) due to the eruption of the Lusi mud volcano (2006-present)
}

\author{
H. Z. Abidin · R. J. Davies · M. A. Kusuma • \\ H. Andreas · T. Deguchi
}

Published online: 9 July 2008

(C) Springer-Verlag 2008

\section{Erratum to: Environ Geol}

\section{DOI 10.1007/s00254-008-1363-4}

In the original article, the location of the dextral offset in the railway line was improperly identified in Fig. 5. The actual deformation was about $100 \mathrm{~m}$ due south from the dismantled bridge. A corrected Fig. 5 is provided below.

The online version of the original article can be found under doi:10.1007/s00254-008-1363-4.

H. Z. Abidin $(\bowtie) \cdot$ M. A. Kusuma $\cdot$ H. Andreas

Geodesy Research Division, Institute of Technology Bandung,

Jl. Ganesha 10, Bandung 40132, Indonesia

e-mail: hzabidin@indo.net.id; hzabidin@gd.itb.ac.id

\section{R. J. Davies}

Department of Earth Sciences, CeREES (Centre for Research into Earth Energy Systems), Durham University Science Labs,

Durham DH1 3LE, UK

e-mail: richard.davies@dur.ac.uk

T. Deguchi

School of Engineering,

University of Tokyo, Tokyo, Japan 


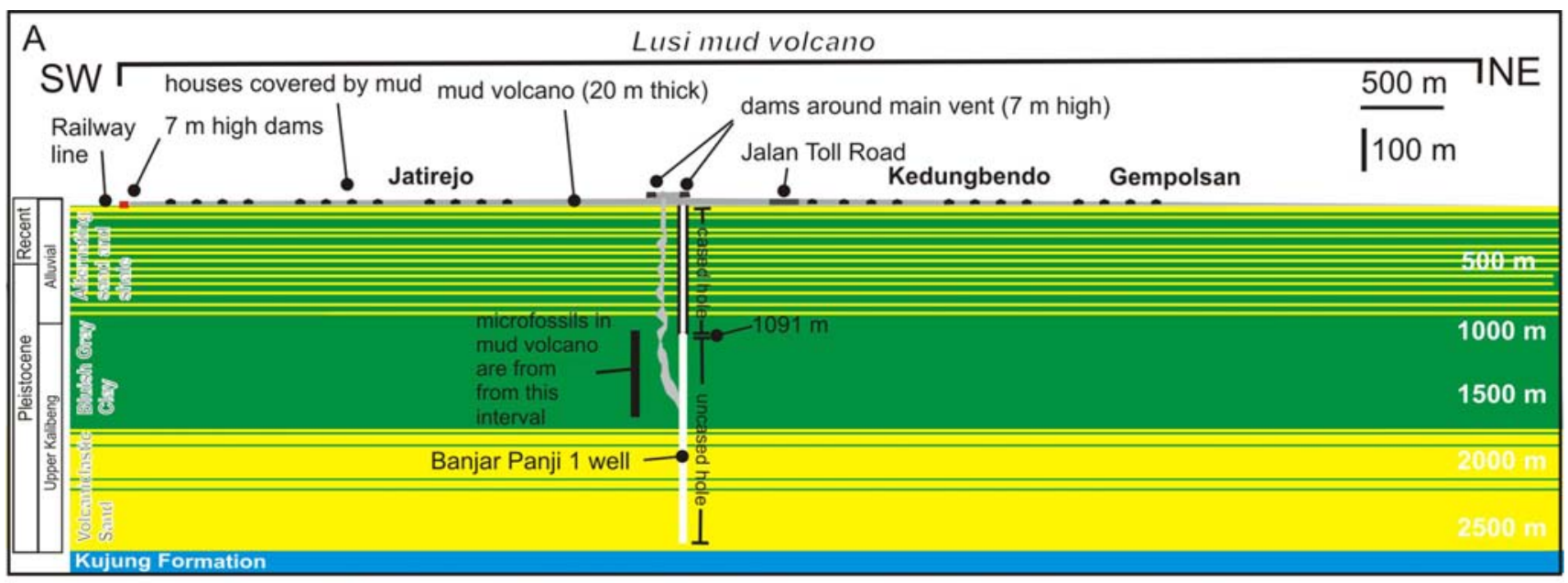

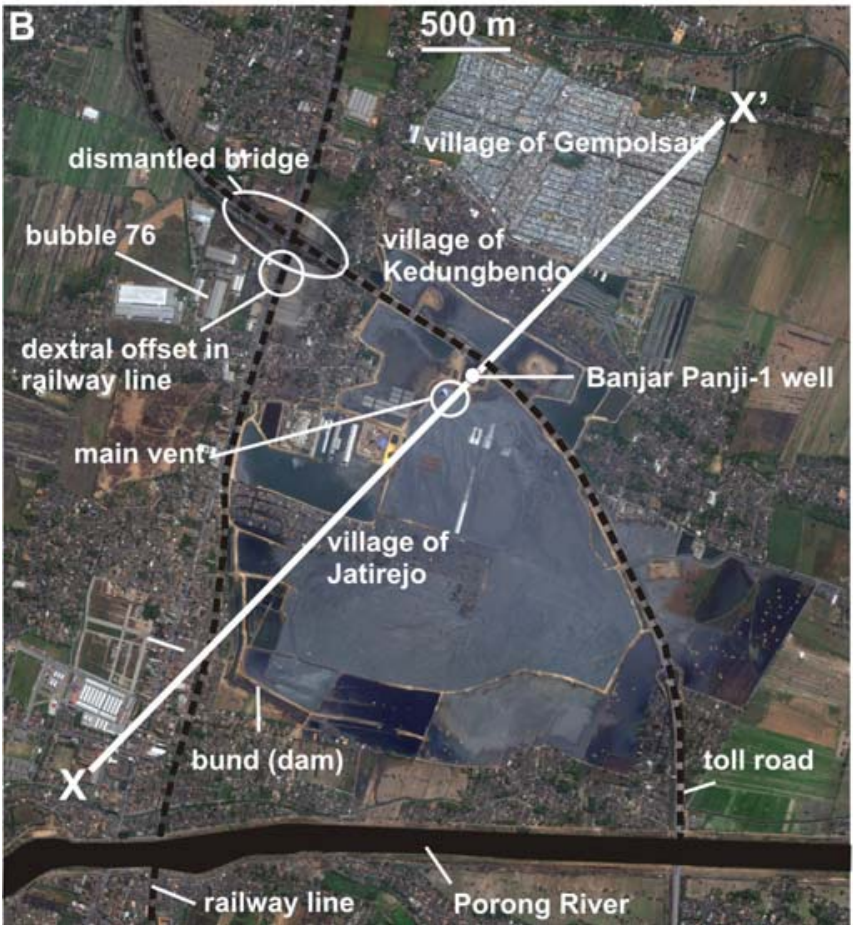

Fig. 5 a Simplified SW-NE cross section through the Lusi mud volcano and subsurface geology. Thin grey lens mud volcano. Black boxes houses. Yellow sandstone. Green mudstone. Blue limestone. b Satellite photograph from October 2006 with features that are

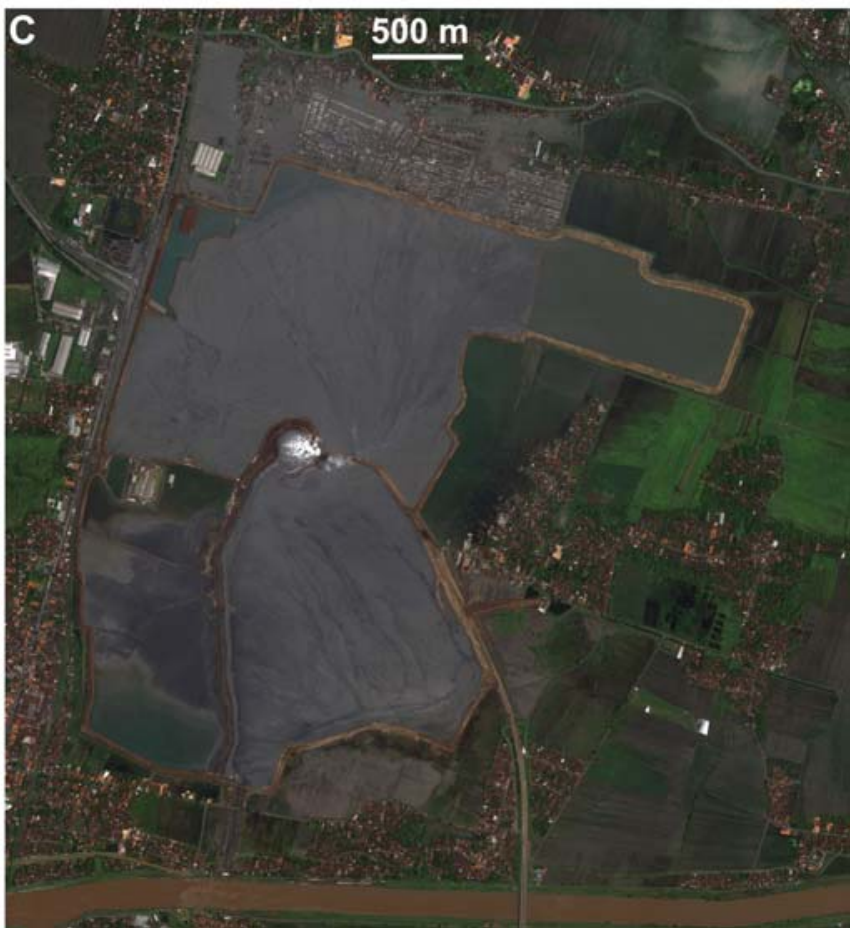

mentioned in the text labeled. c Satellite photograph from January 2008. Satellite images are published with the permission of CRISP. Ikonos Satellite Image ${ }^{\odot}$ CRISP, NUS (2007/2008) 